Ильич - летчик, 2 кандидата наук: Готовцева Эдилия Эдуардовна - кандидат медицинских наук, Копырина Анна Петровна - кандидат экономических наук. Среди экскурсоводов имеются школьники, выбравшие и педагогическую специальность, и технический вид деятельности.

Резюмируя вышеизложенные мы приходим к выводу, что работа в музее помогает в выборе будущей профессии. Хочется отметить, что в выборе профессии автора данной статьи большое влияние оказал Музей космонавтики и авиации Якутии. Работая в музее, автор убедилась в своем призвании - будущего учителя. Именно музей сделал большой вклад в развитии ее как личности, и за что очень благодарна руководителям музея.

Список литературы:

1. Жирков И.Д., Жиркова А.П. Дюпсюнский музей космонавтики и авиации Якутии. Дюпся, 2012.- С.2-3.

2. Йовайша Л.А. Проблемы профессиональной ориентации школьников - М.: Просвещение, 1983. - 128 с.

3. Кон И.С. Психология ранней юности. - М.: Просвещение, 1989, - 187 с.

4. Мудрик А.В. Роль социального окружения в формировании личности подростка. - М.: Знание, 1979. - 39 с.

5. Троянская С.Л. Музейная педагогика и ее образовательные возможности в развитии общекультурной компетентности. - Ижевск, 2007. - С.-30

6. Шергина Н.3., Егорова Р.И. Роль музея в формировании личности детей // Научно-методический электронный журнал «Концепт». - 2016. - Т. 43. - С. 91-93. URL: http://e-koncept.ru/2016/76428.htm.

\title{
Использование методов сказкотерапии для снижения агрессивного поведения младших школьников
}

Янке В.А., студентка, Технический институт (филиал) Северо-Восточного федерального университета, 2. Нерюнгри E-mail: nollon@rambler.ru

Научный руководитель: к.n.н., доцент Иванова В.А.

Сказкотерапия - это один из самых детских методов в психологии, а так же один из самых древних. Сказки служат для детей моральным и нравственным законом, учат их жизни. Зная, как сказка может повлиять на ребенка, можно во многом ему помочь.

В сентябре 2016 г. нами был проведен констатирующий этап исследования агрессивного поведения у детей младшего школьного возраста. Были использованы следующие методики:

1) графическая методика «Кактус» (М. А. Памфилова);

2) Опросник Басса-Дарки (в модификации Г. В. Резапкиной);

3) методика «Несуществующее животное» (М. 3. Друзкевич). 
Экспериментальной базой нашего исследования является МОУ «Гимназия №1 им. С. С. Каримовой» в г. Нерюнгри Республика Саха (Якутия). В экспериментальной группе были задействованы 28 детей из 2 «В» класса в возрасте 7-8 лет.

По данным проведенного исследования нами был констатирован тот факт, что у детей данного возраста преобладает агрессивное поведение. По методике «Кактус» (М. А. Памфилова) в экспериментальной группе из 20 человек у 32\% (6 детей) был выявлен низкий уровень агрессивного поведения. Средний уровень выявлен у 26\% (5 детей). Высокий уровень был выявлен у 42\% (8 детей). По методике Опросник Басса-Дарки (в модификации Г. В. Резапкиной) в группе из 20 человек у 32\% (6 детей) выражена косвенная агрессия, у 37\% (7 детей) преобладает раздражение, у 53\% (10 детей) выявлена словесная агрессия. У 58\% (11 детей) выражена физическая агрессия и обидчивость, 63\% (12 детей) из группы выражена подозрительность, а у 68\% (13 детей) из группы выражен негативизм. По методике «Несуществующее животное» (М. 3. Друзкевич) в группе из 20 человек, высокий уровень был выявлен у 20\% у (4 детей), средний уровень выявлен 25\% у (5 детей), у 55\% (11 детей) был выявлен низкий уровень.

Таким образом, перед нами выступила задача снижения агрессивного поведения у младших школьников средствами сказкотерапии. Данные исследования натолкнули нас на следующую задачу: разработать психолого-педагогическую программу «Уходи злость, уходи!».

За основу для написания программы «Уходи злость, уходи!» была взята программа психолога Е.Е. Варламовой «Программа коррекции деструктивных агрессивных проявлений в поведении детей младшего школьного возраста».

Цель программы: обучить детей способам выражения гнева через приемлемую форму, приемам саморегуляции, умению владеть собой в различных жизненных ситуациях.

Программа направлена на решение следующих задач:

1. Обучить детей навыкам контроля и способам снижения агрессивного поведения.

2. Обучить детей социально приемлемым формам выражения агрессивного поведения.

3. Развить у детей, чувство сопереживания, эмпатию.

Методы:

1) игротерапия (ролевые и подвижные игры);

2) элементы изотерапии (рисование, лепка);

3) элементы сказкотерапии (ролевое проигрывание ситуаций, рассказывание и сочинение сказок).

Дополнительные методы: беседа, релаксация.

Форма работы: групповая.

Контингент: учащиеся младшего школьного возраста.

Продолжительность: 24 занятия по 40 минут, 2 раза в неделю.

Ожидаемые результаты: в результате прохождения программы дети научаться навыкам контроля и способам снижения агрессивного поведения, научаться выражать агрессивное поведение социально приемлемыми формами, у детей появится способность к сопереживанию.

Структура занятий состоит из трех этапов:

I. Вводная часть.

II. Основная часть. 
III. Заключительная часть.

Вводная часть включает в себя ритуал приветствия, который направлен на создание атмосферы доверия; основная часть содержит методы работы, которые направлены на решение вышеуказанных задач, заключительная часть - ритуал прощания нацелен на подведение итогов занятия и сплочение коллектива.

Рассмотрим часть содержания тематического плана программы «Уходи злость, уходи!» для снижения агрессивного поведения младших школьников средствами сказкотерапии (таблица 1).

Таблица 1

Тематическое планирование занятий снижения агрессивного поведения у детей младшего школьного возраста

\begin{tabular}{|c|c|c|c|}
\hline № & Тема & Цель & Методы и средства \\
\hline 1. & $\begin{array}{l}\text { Занятие } 1 . \\
\text { «Знакомство» }\end{array}$ & $\begin{array}{l}\text { Знакомство и установление } \\
\text { эмоционально-положительного } \\
\text { контакта с детьми, знакомство } \\
\text { детей друг с другом. Выбор } \\
\text { ритуала } \\
\text { приветствия.Установление правил } \\
\text { проведения занятий }\end{array}$ & $\begin{array}{l}\text { Игротерапия - } \\
\text { «Опиши друга», } \\
\text { «Комплименты», } \\
\text { «Аплодисменты по кругу» }\end{array}$ \\
\hline 2. & $\begin{array}{l}\text { Занятие } 2 . \\
\text { «Давайте жить } \\
\text { дружно» }\end{array}$ & $\begin{array}{l}\text { Снять эмоциональное напряжение, } \\
\text { настроить детей на совместную } \\
\text { работу, обучить детей } \\
\text { безконфликтному поведению }\end{array}$ & $\begin{array}{l}\text { Игротерапия - } \\
\text { «Два барабана», } \\
\text { «Уходи злость, уходи!», } \\
\text { «Доброе животное», } \\
\text { «Морщинки»; } \\
\text { Сказкотерапия - } \\
\text { «Придумай добрый } \\
\text { конец» }\end{array}$ \\
\hline 3. & $\begin{array}{l}\text { Занятие } 3 . \\
\text { «Мои эмоции» }\end{array}$ & $\begin{array}{l}\text { Настроить детей на общение друг } \\
\text { с другом, научить детей понимать } \\
\text { и различать свои эмоции, дать } \\
\text { каждому ребенку возможность } \\
\text { почувствовать себя в центре } \\
\text { внимания }\end{array}$ & $\begin{array}{l}\text { Игротерапия - } \\
\text { «Эхо», } \\
\text { «Гнев, ссора», } \\
\text { «Выставка», } \\
\text { «Эмоции в моем теле», } \\
\text { Сказкотерапия - } \\
\text { «Притча о змее» } \\
\text { Релаксация - } \\
\text { «Место покоя» }\end{array}$ \\
\hline 4. & $\begin{array}{l}\text { Занятие } 4 . \\
\text { «Маленькое } \\
\text { приведение» }\end{array}$ & $\begin{array}{l}\text { Обучение детей отреагированию } \\
\text { собственного гнева приемлемыми } \\
\text { способами, отреагирование } \\
\text { ситуации в целом. Формирование } \\
\text { осознания собственных эмоций, а } \\
\text { также чувств других людей, } \\
\text { развитие эмпатии }\end{array}$ & $\begin{array}{l}\text { Игротерапия - } \\
\text { «Подари улыбку», } \\
\text { «Маленькое привидение», } \\
\text { «Жужа»; } \\
\text { «Пластическое } \\
\text { изображение гнева» } \\
\text { Беседа - } \\
\text { «Как можно сделать } \\
\text { ребенка агрессивным» } \\
\text { Релаксация - } \\
\text { «Апельсин» }\end{array}$ \\
\hline
\end{tabular}


Мы думаем, что разработанная нами психолого-педагогическая программа «Уходи злость, уходи!» сможет снизить агрессивное поведение у детей младшего школьного возраста, а также она может быть использована учителями, педагогамипсихологами, педагогами дополнительного образования и студентами для прохождения практики.

Список литературы:

1. Елисеев О.П. Практикум по психологии личности. - М.: Эксмо, 2009. - 578 с.

2. Лебедева Л.Д. Практика арт-терапии: подходы, диагностика, система занятий. - СПб.: Речь, 2003. - 539 с. 